University of Nebraska - Lincoln

DigitalCommons@University of Nebraska - Lincoln

USDA Forest Service / UNL Faculty Publications U.S. Department of Agriculture: Forest Service --

National Agroforestry Center

2003

\title{
Factors Related to Body Condition of Nestling Burrowing Owls in Buffalo Gap National Grassland, South Dakota
}

\author{
Randall L. Griebel \\ University of Nebraska-Lincoln \\ Julie A. Savidge \\ Colorado State University - Fort Collins, julie.savidge@colostate.edu
}

Follow this and additional works at: https://digitalcommons.unl.edu/usdafsfacpub

Part of the Forest Sciences Commons

Griebel, Randall L. and Savidge, Julie A., "Factors Related to Body Condition of Nestling Burrowing Owls in Buffalo Gap National Grassland, South Dakota" (2003). USDA Forest Service / UNL Faculty Publications. 125.

https://digitalcommons.unl.edu/usdafsfacpub/125

This Article is brought to you for free and open access by the U.S. Department of Agriculture: Forest Service -National Agroforestry Center at DigitalCommons@University of Nebraska - Lincoln. It has been accepted for inclusion in USDA Forest Service / UNL Faculty Publications by an authorized administrator of DigitalCommons@University of Nebraska - Lincoln. 


\title{
Factors Related to Body Condition of Nestling Burrowing Owls in Buffalo Gap National Grassland, South Dakota
}

\author{
Randall L. Griebel ${ }^{1,3,4}$ and Julie A. Savidge ${ }^{2}$
}

\begin{abstract}
We analyzed the body condition of nestling Burrowing Owls (Athene cunicularia) at Buffalo Gap National Grassland during the summers of 1999 and 2000. In 1999, which had a wet spring, body condition was negatively related to brood size and distance from nest to colony edge. There was no relationship between body condition and brood size during 2000 , which had normal precipitation. In 2000, nestlings of early arriving pairs were in better body condition than those that arrived later. The variance in body condition within a brood was not related to brood size. Received 29 August 2002, accepted 28 February 2003.
\end{abstract}

Burrowing Owls (Athene cunicularia) are declining in parts of their range, and it is im-

\footnotetext{
${ }^{1}$ School of Natural Resource Sciences, Univ. of Nebraska-Lincoln, Lincoln, NE 68583-0819, USA.

${ }^{2}$ Dept. of Fishery and Wildlife Biology, Colorado State Univ., Fort Collins, CO 80523-1474, USA.

${ }^{3}$ Current address: Hell Canyon Ranger District, Black Hills National Forest, 330 Mount Rushmore Rd., Custer, SD 57730-1928, USA.

${ }^{4}$ Corresponding author; e-mail: rgriebel@fs.fed.us
}

portant that wildlife managers understand factors associated with the health of young owls and their subsequent ability to survive and reproduce. Body condition has been used as a measure of health for a number of bird species (Chappell and Titman 1983, Hepp et al. 1986, Hohman and Taylor 1986, Wellicome 2000), and has been defined as the fitness of a particular individual relative to its present and future energy demands and activities (Owen and Cook 1977). Burrowing Owl nestlings typically show a large amount of variability in growth rates (Landry 1979, Bellocq 1997) and body condition (Wellicome 2000), largely attributable to the owl's asynchronous hatching; early nestlings get a greater proportion of food, which results in faster growth rates. In Canada, Wellicome (2000) found that supplementally fed pairs of Burrowing Owls had broods in better body condition than unsupplemented pairs during the two years of his study.

We analyzed the relationship between nest- 
ling body condition and brood size, pair arrival date on the breeding grounds, nest distance to the colony edge, and nearest neighbor distance. We also analyzed variation in body condition within brood as a function of brood size, predicting small broods should show less variation because of more equitable provisioning.

\section{METHODS}

We conducted our study from 1 April to 1 August of 1999 and 2000 in the Wall District of Buffalo Gap National Grassland in southwestern South Dakota $\left(43^{\circ} 44^{\prime} \mathrm{N}, 102^{\circ} 20^{\prime}\right.$ $\mathrm{W})$. The District has approximately 220 prairie dog (Cynomys ludovicianus) colonies that range in size from 0.5 to 700 ha, with a total area of about 4,000 ha. The study area was primarily in the Conata and Scenic Basins, both of which contain numerous prairie dog colonies. All colonies were subject to rotational grazing by domestic cattle, which has taken place on the National Grassland since 1900 (MacCracken et al. 1985a, 1985b). During the period of our research the mean temperature in 1999 was cooler $\left(14.9^{\circ} \mathrm{C}\right)$ and the mean precipitation was greater $(8.9 \mathrm{~cm})$ than the 100-year mean temperature and precipitation $\left(15.6^{\circ} \mathrm{C}\right.$ and $\left.6.1 \mathrm{~cm}\right)$ for the same months (National Climate Data Center 2000). During 2000, both temperature and precipitation $\left(15.9^{\circ} \mathrm{C}\right.$ and $\left.7.1 \mathrm{~cm}\right)$ were closer to normal (National Climate Data Center 2000).

We searched prairie dog colonies for Burrowing Owl nests at least twice weekly by foot, all terrain vehicle, and $4 \times 4$ truck. We conducted surveys from 2 April to 15 June in 1999 and from 11 April to 15 June in 2000; no owls were present on the study site prior to surveys. All nest locations were recorded on geographic information system (GIS) maps provided by the U.S. Forest Service.

Counts of young owls usually were conducted at distances $\geq 100 \mathrm{~m}$ using a windowmounted spotting scope within a vehicle. We also scanned nearby satellite burrows (nonnest burrows used by the young) for activity. We spent a minimum of $15 \mathrm{~min}$ at each nest site, and frequently up to $45 \mathrm{~min}$ to get an accurate count. We visited nest sites at least twice a week but usually three to four times a week during this part of the study. We considered brood size to be the maximum number of young seen at each nest site prior to fledging.

We determined the date of arrival on the breeding grounds of individual pairs by the method of Wellicome (2000). Arrival dates for 1999 were not included in the analysis due to the unusually wet weather that prevented us from reaching some of the prairie dog colonies. We measured to the nearest meter the distance from a nest location to the edge of the prairie dog colony (i.e., the extent of the clipped vegetation). We determined the location of each nest $( \pm 5 \mathrm{~m})$ with a global positioning system and incorporated them into the existing GIS. We determined nearest neighbor distance (the next closest nest site, even if that nest was located in a different prairie dog colony) using ArcView ver. 3.0 (Environmental Systems Research Institute, Inc. 1996).

We trapped Burrowing Owl nestlings from 19 June to 26 July 1999 and from 23 June to 1 July 2000. Nest sites selected for trapping were located in 21 (1999) and 16 (2000) prairie dog colonies of various sizes (1.5-700 ha). The nest was considered for trapping when the entire brood was consistently seen above ground, but before they started consistently using satellite burrows. Traps (similar to those used by Haug 1985) typically were set early in the morning or early in the evening to prevent heat-related stress. In order to obtain an accurate measure of mean body condition for a brood, only those nests at which at least one third of the brood was captured were used in the analyses; thus, two nests were excluded in 1999 but none in 2000.

We determined nestling body mass to the nearest $0.5 \mathrm{~g}$ with a spring scale. We also measured the length $( \pm 0.5 \mathrm{~mm})$ of the culmen, tarsus, and unflattened wing chord (from flexed wrist to the end of the longest primary) to estimate structural size.

We used body mass corrected for structural size to provide a relative index of body condition for each bird (White and Bolen 1984, Ringleman and Szymczak 1985, Dufour et al. 1993, Wellicome 2000). We obtained a single measure of structural size for each individual through principal components analysis (PROC PRINCOMP; SAS Institute, Inc. 1999) on the correlation matrix of the three structural measurements (culmen, tarsus, wing chord). Results were analyzed for all nestlings trapped 
and separate indices were generated for each year. The first principal component described positive covariation among the three variables (coefficients for 1999: 0.60, 0.58, 0.55; coefficients for 2000: $0.58,0.59,0.57$, corresponding to tarsus, wing chord, and culmen, respectively) and accounted for $80.4 \%$ (1999) and $87.0 \%$ (2000) of the total original variance. Each bird's score along this axis (PC1 scores) served as the measurement of its structural size. The body condition index for each bird was then determined by using the mass residuals from the linear regression of mass on PC1. Thus, birds with positive residuals were heavier than what would be expected, and birds with negative residuals were lighter than what would be expected for that particular structural size (Wellicome 2000).

We used SAS (SAS Institute, Inc. 1999) for all statistical analyses. We tested all variables for normality and transformed to LOG $(y+1)$ if necessary. We used stepwise multiple regression to analyze the relation between the dependent variable mean body condition of broods and the independent variables brood size, distance to edge, nearest neighbor distance, and arrival date (2000 only). We used an entry $P$ value of $\leq 0.15$ for selecting variables to be retained in the model. The variation in body condition for different brood sizes, as expressed by the SD of the mean body condition of broods, also was examined using one-way ANOVA. We categorized brood sizes into: (1) small, two to three nestlings; (2) medium, four to five nestlings; and (3) large, six to seven nestlings. Results were considered significant at $P \leq 0.05$. Data were analyzed separately for each year due to the differences in weather and prairie dog activity.

\section{RESULTS AND DISCUSSION}

We trapped 94 burrowing owl nestlings in 1999 and 97 in 2000. Mean body condition was obtained for 26 nests in each year. Mean brood size for those nests was 4.2 (range: 17) and 4.6 (range: 2-8) in 1999 and 2000, respectively. The mean nearest neighbor distance and distance to edge was $255.9 \mathrm{~m}$ (range: $38-1,105 \mathrm{~m}$ ) and $71.6 \mathrm{~m}$ (range: $14-$ $176 \mathrm{~m}$ ) in 1999 , and $255.8 \mathrm{~m}$ (range: $56-997$ $\mathrm{m}$ ) and $97.3 \mathrm{~m}$ (range: $1-450 \mathrm{~m}$ ) in 2000, respectively. The mean arrival date in 2000 was 23 April (range: 11 April to 4 May). Brood size (BS) and distance to edge (DE) were retained in the multiple regression model for 1999 and both were negatively related to body condition $(n=26 ; \mathrm{y}=37.70-3.34(\mathrm{BS})-$ 5.51(DE); $\left.R^{2}=0.24, P=0.040\right)$. In 2000, only arrival date (AD) was retained; pairs that arrived earlier on the nesting grounds had broods in better body condition than those that arrived later $(n=26 ; \mathrm{y}=32.94-10.10(\mathrm{AD})$; $\left.R^{2}=0.16, P=0.043\right)$. The $t$ and $P$ values of the individual parameters retained in the models are as follows: (BS) $t=-2.39, P=0.026$; (DE) $t=-1.63, P=0.116$; and (AD) $t=$ $-2.14, P=0.043$. Standard deviations of the mean body condition did not differ among brood sizes (1999: $n=22, F_{2,19}=0.42, P=$ 0.67; 2000: $n=24, F_{2,21}=0.09, P=0.92$ ).

Larger broods were in worse body condition than smaller broods in 1999. Brood size has been found to be negatively related to nestling growth rates (Landry 1979, Bellocq 1997). Precipitation was above normal in 1999, which may have affected how many young the adults could adequately feed. Wellicome (2000) noted that nestling mortality increased during periods of heavy rain, and especially when rain fell for several consecutive days. Adults may not be able to hunt during these events. Nests located closer to the edge had broods in better condition in 1999. Perhaps pairs nesting closer to the edge can easily shift their hunting efforts to resources off the colony if prey is depressed on the prairie dog colony.

Pair arrival date was negatively related to nestling body condition in 2000, the only year examined. Presumably, pairs that arrive earlier on the breeding grounds are able to secure good territories with more food resources than those forced to nest in marginal habitat. While not significant for our 26 nests, when analyzed as part of our overall study (Griebel 2000), there was a significant but weak positive relation between arrival date and nest location (i.e., early arriving pairs nested closer to the edge of the colony) ( $n=126, t=2.07, R^{2}=$ $0.03, P=0.040)$. Even though nearest neighbor distance was positively related to brood size and the number of young fledged per nest in 2000 (Griebel 2000), these factors were not related to body condition of nestlings. Since there were no differences in the variation in body condition in relation to brood size, brood 
sizes may be adjusted early in the brood stage (e.g., by starvation); those young that survive the 10-14 days prior to emerging from the nest burrow may consist of a brood size the adults can adequately feed during a normal year.

The low amount of variation explained by the multiple regression models indicates other factors such as nearby food resources are associated with nestling body condition. Additional studies under different weather conditions and information on corresponding resource availability would be useful.

\section{ACKNOWLEDGMENTS}

We thank M. Wilbur, A. Noe, N. Seltsam, and C. Laskaris for their hard work and long hours in the field. We are grateful to J. G. Sidle, USDA Forest Service-Chadron, for providing funding for this project and the Wall District office of Buffalo Gap National Grassland, especially D. Sargent, for logistic help. R. M. Case and M. M. Beck provided valuable ideas and suggestions. We thank E. E. Blankenship and J. R. zumBrunnen for statistical help; GIS support was provided by J. Fisher. J. A. Smallwood, M. S. Martell, M. J. Desmond, and J. Belthoff reviewed the manuscript and provided helpful comments. The Univ. of Nebraska-Lincoln School of Natural Resource Sciences, the Center for Great Plains Studies, and the South Dakota Ornithologists Union provided additional funding for this project.

\section{LITERATURE CITED}

BellocQ, M. I. 1997. Ecology of the Burrowing Owl in agrosystems of central Argentina. Pp. 52-57 in The Burrowing Owl: its biology and management (J. L. Lincer and K. Steenhof, Eds.). Raptor Research Foundation, Inc., Boise, Idaho.

Chappell, W. A. AND R. D. Titman. 1983. Estimating reserve lipids in Greater Scaup (Aythya marila) and Lesser Scaup (A. affinis). Can. J. Zool. 61:3538.

Dufour, K. W., C. D. AnKney, and P. J. WeatherHEAD. 1993. Nonrepresentative sampling during waterfowl banding: emphasis on body condition. J. Wildl. Manage. 57:741-751.

Environmental Systems Research Institute, InC.
1996. Getting to know ArcView: the geographical information system (GIS) for everyone. Geoinformational International, Cambridge, United Kingdom.

GRIEBEL, R. L. 2000. Ecological and physiological factors affecting nesting success of Burrowing Owls in Buffalo Gap National Grassland. M.Sc. thesis, Univ. of Nebraska, Lincoln.

HaUG, E. A. 1985. Observations on the breeding ecology of Burrowing Owls in Saskatchewan. M.Sc. thesis, Univ. of Saskatchewan, Saskatoon, Canada.

Hepp, G. R., R. J. Blohm, R. E. Reynolds, J. E. Hines, AND J. D. NiCHOLLS. 1986. Physiological condition of autumn-banded Mallards and its relationship to hunting mortality. J. Wildl. Manage. 50:177-183.

Hohman, W. L. AND T. S. TAYLOR. 1986. Indices of fat and protein for Ring-necked Ducks. J. Wildl. Manage. 50:209-211.

LANDRY, R. E. 1979. Growth and development of the Burrowing Owl, Athene cunicularia. M.Sc. thesis, California State Univ., Long Beach.

MacCracken, J. G., D. W. URESK, AND R. M. HANSEN. 1985a. Burrowing Owl foods in the Conata Basin, South Dakota. Great Basin Nat. 45:287-290.

MacCracken, J. G., D. W. Uresk, And R. M. Hansen. 1985b. Vegetation and soils of Burrowing Owl nest sites in the Conata Basin, South Dakota. Condor 87:152-154.

National Climate Data Center. 2000. National climate data center home page. http://www.ncdc. noaa.gov/ol/ncdc.html.

Owen, M. AND W. A. CoOK. 1977. Variations in body weight, wing length, and condition of Mallards Anas platyrhynchos platyrhynchos and their relationship to environmental changes. J. Zool. 183: 377-395.

Ringleman, J. K. And M. R. Szymczak. 1985. A physiological condition index for wintering Mallards. J. Wildl. Manage. 49:564-568.

SAS InstituTe, InC. 1999. The SAS system for windows, ver. 8. SAS Institute, Inc., Cary, North Carolina.

Wellicome, T. I. 2000. Effects of food on reproduction in Burrowing Owls (Athene cunicularia) during three stages of the breeding season. Ph.D. diss., Univ. of Alberta, Calgary, Canada.

White, R. J. And E. G. Bolen. 1984. Variation in winter fat deposits and condition indices of Mallards. J. Wildl. Manage. 48:1370-1373. 